\title{
Exposure assessment of adult consumers in Serbia, Greece and Croatia to deoxynivalenol and zearalenone through consumption of major wheat-based products
}

\author{
I. Djekic $^{1^{*}}$, B. Udovicki ${ }^{1}$, J.G. Kljusurić ${ }^{2}$, M. Papageorgiou ${ }^{3}$, J. Jovanovic ${ }^{3}$, C. Giotsas ${ }^{4}$, J. Djugum ${ }^{2,5}$, N. Tomic ${ }^{1}$ and $^{-}$ \\ A. Rajkovic ${ }^{1,3}$ \\ ${ }^{1}$ Department of Food Safety and Quality Management, University of Belgrade, Faculty of Agriculture, Nemanjina 6, 11080 \\ Belgrade, Republic of Serbia; ${ }^{2}$ Faculty of Food Technology and Biotechnology, University of Zagreb, Pierottijeva ul. 6, 10000 \\ Zagreb, Croatia; ${ }^{3}$ Food Technology Alexander Technological Educational Institute of Thessaloniki, POB 141, Thessaloniki \\ 574. 00, Greece; ${ }^{4}$ Department of Food Safety and Food Quality, Faculty of Bioscience Engineering, Ghent University, Campus \\ Coupure, A, Coupure Links 653, 9000 Ghent, Belgium; ${ }^{5}$ Ministry of Agriculture, Ulica grada Vukovara 78, Zagreb, Croatia; \\ idjekic@agrif.bg.ac.rs
}

Received: 20 March 2019 / Accepted: 6 June 2019

(c) 2019 Wageningen Academic Publishers

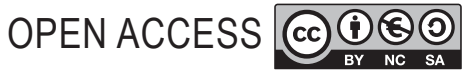

RESEARCH ARTICLE

\begin{abstract}
The main objective of this research was to perform an exposure assessment of mycotoxin intake through consumption of wheat-based products in Serbia, Croatia, and Greece by estimating deoxynivalenol (DON) and zearalenone (ZEA) exposure from wheat. Food consumption survey of wheat-based products has been performed during 2017 in the three countries with at least 1000 interviewees per country. Values for the concentration of DON and ZEA were extracted from available research published in this decade. Finally, a Monte Carlo analysis of 100,000 simulations was performed to estimate the intake of DON and ZEA from consumption of wheat-based products. Results revealed that the estimated daily wheat-borne intake of DON of the adult population in Croatia was $0.121 \mu \mathrm{g} / \mathrm{kg}$ bw/day, followed by Greece with $0.181 \mu \mathrm{g} / \mathrm{kg}$ bw/day and Serbia with $0.262 \mu \mathrm{g} / \mathrm{kg}$ bw/day. This shows that $0.25 \%$ of Croatian, $1.19 \%$ of Greek and 3.96\% of Serbian adult population is exposed to higher daily dietary intakes of DON than recommended. Estimated daily wheat-borne intake of ZEA was $0.017 \mu \mathrm{g} / \mathrm{kg}$ bw $/$ day in Greece, $0.026 \mu \mathrm{g} / \mathrm{kg}$ bw/day in Croatia and $0.050 \mu \mathrm{g} / \mathrm{kg}$ bw/day in Serbia. Higher intake of ZEA is associated with $0.62 \%$ of the Greek population, followed by $0.95 \%$ Croatian and $2.25 \%$ of Serbian citizens. This type of research is helpful to assess accurately the risk by DON/ZEA intake associated with the consumption of wheat-based products by consumers in these three countries. Distributions of potential mycotoxin intakes were highly right-skewed.
\end{abstract}

Keywords: mycotoxins, wheat products, consumption risks, Monte Carlo

\section{Introduction}

Wheat (Triticum aestivum) is considered as one of the most important food grains and ranks second in the total production of cereal crops behind maize (GonzalezOsnaya and Farres, 2011). In 2017, world wheat output was estimated at 754.8 million tons (FAO, 2018). In wheatdominant countries such as south-European countries (EU, 2017), wheat may be categorised as the primary source of calories and protein originated from plant sources in the human diet (Khaneghah et al., 2018). There is a wide range of commercial, traditional and modern wheat products due to the great variation in ingredients as well as rising and baking methods (Sandvik et al., 2018). Being consumed on such scale throughout the world a prevention of wheat contamination with mycotoxins is crucial to food safety (Calori-Domingues et al., 2016).

Mycotoxins are a series of secondary metabolites generated by various fungi species (Liu et al., 2015). Under favourable conditions, cereals may be contaminated by toxigenic fungal strains throughout the food chain (Savi et al., 2014). Among the fungal diseases of wheat, Fusarium head blight (FHB) is one of the most damaging (Siou et al., 2015). The Fusarium 
species predominantly associated with FHB are Fusarium graminearum, Fusarium avenaceum and Fusarium culmorum (Bottalico and Perrone, 2002). Infection and colonisation of cereal heads by these pathogens not only reduce crop yield but also results in mycotoxin contamination (Kimura et al., 2007). Mycotoxins most frequently encountered in FHB of wheat are deoxynivalenol (DON) with its derivatives and zearalenone (ZEA), both produced by F. graminearum and F. culmorum (Bottalico and Perrone, 2002). DON belongs to a major class of mycotoxins known as trichothecenes. All mycotoxins in this group have small molecular weights, the same basic ring structure, and a characteristic 12,13-epoxide group ( $\mathrm{He}$ et al., 2010). Various surveys for the presence of DON and ZEA have indicated the world-wide occurrence of these mycotoxins primarily in cereals, such as wheat (Denardi de Souza et al., 2015; Khaneghah et al., 2018; Li et al., 2016; Manova and Mladenova, 2009; Savi et al., 2016; Stanciu et al., 2015; Vidal et al., 2016).

Based on animal studies it was established that DON can affect the immune system food consumption, growth, reproduction, neuroendocrine signalling, and intestinal function (Pestka, 2010; Pinton et al., 2010). Concerning toxicity in humans there is historical evidence suggesting that DON causes acute gastroenteritis with had nausea, diarrhoea and vomiting as their primary symptoms (Pestka, 2010). The toxicity of DON initiated many countries to set up regulations for its control in wheat grains and their products intended for human consumption (Savi et al., 2016). As DON is usually accompanied with his acetylated and modified forms Joint FAO/WHO Expert Committee on Food Additives (JEFCA) established a provisional maximum tolerable daily intake (PMTDI) of $1 \mu \mathrm{g} / \mathrm{kg}$ body weight per day for the total amount of DON and its acetylated derivatives, 3-acetyldeoxynivalenol (3ADON) and 15-acetyldeoxynivalenol (15-ADON) (FAO/ WHO, 2010). This was also confirmed by CONTAM Panel where TDI of $1 \mu \mathrm{g} / \mathrm{kg}$ bw/day was established for the sum of DON, 3-ADON, 15-ADON and DON-3-glucoside and an acute reference dose (ARfD) of $8 \mu \mathrm{g} / \mathrm{kg}$ bw was defined (Knutsen et al., 2017). Presence of DON derivatives were rarely investigated in countries included in the present study. Therefore, the exposure assessment for the whole group was evaluated based only on DON occurrence which could lead to certain level of underestimation.

ZEA is a phenolic resorcylic acid lactone mycotoxin with dominating biological oestrogenic activity, i.e. the ability to act like the endogenous steroidal sex hormone 17 b-oestradiol (EFSA, 2017). The current tolerable daily intake (TDI) for ZEA is $0.25 \mu \mathrm{g} / \mathrm{kg}$ bw/day established in 2011 by the EFSA Panel for Contaminants in the Food Chain (EFSA, 2011b). In 2016 the CONTAM Panel found it appropriate to set a group TDI of $0.25 \mu \mathrm{g} / \mathrm{kg}$ bw per day expressed as ZEA equivalents for ZEA and its modified forms (phase I and phase II metabolites) (EFSA, 2016).

Exposure assessment implies a calculation of mycotoxin occurrence in food joint with analysis of consumption of the same food in a particular population (Pacin et al., 2011). In the mycotoxin field, exposure assessment methods are mainly deterministic. However, EFSA encourages the use of probabilistic approaches to capture the variability in refined models (EFSA, 2011a). Therefore, food consumption patterns play a significant role in all risk assessment activities in order to estimate the impact of different nutrients and food hazards on consumer health (Vilone et al., 2014).

The aim of this study was to provide a quantitative exposure assessment to DON and ZEA through the consumption of wheat-based products in three countries (Serbia, Croatia, and Greece) using food consumption survey and established Monte Carlo simulations.

\section{Materials and methods}

\section{Consumer survey}

Food consumption survey of wheat-based products has been performed during 2017 in all countries. A questionnaire has been designed according to general principles and EFSA guidelines on data collection of national food consumption (EFSA, 2009). To the best of our knowledge, this study is currently the only survey to provide individual consumptions data on wheat-based products in these three countries.

The tested population sample was predetermined in terms of age (all respondents were 20 years or older), number of respondents per country (1000) and locality of residence (large cities). The recruitment of the respondents was performed outdoors, in front of various food retails, randomly choosing citizens, as well as using an existing professional and family network, and by further dissemination of the questionnaire through their networks. The number of participants that were approached in the survey but refused to participate was below $5 \%$ for each country. Brief explanations about aims of the research were given to the respondents before interviewing to avoid ambiguity.

Demographic characteristics were not stratified due to restrictions in resources when interviewing three countries at the same time (Table 1). The authors recognise that this method does not provide a truly random sample of consumers, but instead, represents a 'convenience sample' and evaluates the dietary habits of wheat-based products of urban population. In spite of its limited size per country, the sample used here is comparable to similar published 
Table 1. Demographic and consumption profile of the sample $(n=3,014){ }^{1,2}$

\begin{tabular}{|c|c|c|c|c|c|c|}
\hline & & & Total & Serbia & Croatia & Greece \\
\hline \multirow[t]{2}{*}{ Gender } & \multicolumn{2}{|l|}{ male } & $1,445(47.9 \%)$ & $463(45.8 \%)$ & $481(48 \%)$ & $501(50.1 \%)$ \\
\hline & \multicolumn{2}{|l|}{ female } & $1,569(52.1 \%)$ & $548(54.2 \%)$ & $522(52 \%)$ & $499(49.9 \%)$ \\
\hline \multicolumn{3}{|l|}{ Total } & $3,014(100 \%)$ & $1,011(100 \%)$ & $1,003(100 \%)$ & $1000(100 \%)$ \\
\hline \multirow[t]{5}{*}{ Age } & \multicolumn{2}{|c|}{ less than 24 years } & $788(26.1 \%)$ & $330(32.6 \%)$ & $114(11.4 \%)$ & $344(34.4 \%)$ \\
\hline & \multicolumn{2}{|l|}{$25-34$ years } & $715(23.7 \%)$ & $312(30.9 \%)$ & $227(22.6 \%)$ & $176(17.6 \%)$ \\
\hline & \multicolumn{2}{|l|}{$35-49$ years } & $563(18.7 \%)$ & $181(17.9 \%)$ & $201(20 \%)$ & $181(18.1 \%)$ \\
\hline & \multicolumn{2}{|l|}{$50-64$ years } & $519(17.2 \%)$ & $112(11.1 \%)$ & $233(23.2 \%)$ & $174(17.4 \%)$ \\
\hline & \multicolumn{2}{|l|}{ Over 65 years } & $429(14.2 \%)$ & $76(7.5 \%)$ & $228(22.7 \%)$ & $125(12.5 \%)$ \\
\hline \multirow{2}{*}{\multicolumn{3}{|c|}{$\begin{array}{l}\text { Average body weight }[\mathrm{kg}] \\
\text { Average daily intake of wheat from wheat-based products [kg] }\end{array}$}} & $73.14 \pm 15.03$ & $72.97 \pm 16.25$ & $74.21 \pm 13.93$ & $72.23 \pm 14.77$ \\
\hline & & & $0.087 \pm 0.061$ & $0.081 \pm 0.056^{A}$ & $0.070 \pm 0.054^{B}$ & $0.110 \pm 0.064^{C}$ \\
\hline \multirow{3}{*}{\multicolumn{2}{|c|}{$\begin{array}{l}\text { Average daily intake of wheat from } \\
\text { wheat-based products [g/per } \mathrm{kg} \mathrm{bw]}\end{array}$}} & male & $1.194 \pm 0.836$ & $1.128 \pm 0.734^{B}$ & $0.884 \pm 0.720^{\mathrm{a}, \mathrm{A}}$ & $1.552 \pm 0.893^{C}$ \\
\hline & & female & $1.257 \pm 0.947$ & $1.129 \pm 0.836^{A, B}$ & $1.039 \pm 0.765^{b, A}$ & $1.625 \pm 1.110^{B}$ \\
\hline & & total & $1.227 \pm 0.895$ & $1.129 \pm 0.791^{\mathrm{A}}$ & $0.965 \pm 0.748^{\mathrm{B}}$ & $1.588 \pm 1.007^{C}$ \\
\hline
\end{tabular}

consumer surveys related to food consumption patterns and the results under a certain dose of caution may be projected to the general population level of the three countries.

A structured three-section questionnaire was developed considering similar research on risk assessments/exposure assessment published in scientific manuscripts (EFSA, 2009; Pacin et al., 2011). The first section included general demographic information about the respondents, namely gender, age, and weight (Table 1). The second section examined consumers' consumption patterns of bread as the most consumed wheat-based products and covered frequency of consumption of bread and number of slices usually consumed. The third section gave the respondents opportunity to analyse consumption of wheat-based products in the last seven days giving them the possibility to state type of product and quantity of consumed products (in grams).

Before the field research, authors placed all investigated wheat-based products on plates/dishes as usually served, determined values of product portions (in grams) and made photographs of the products. In terms of visual aid, the interviewees were provided with photographs of wheatbased products and provided values of portions. Wheat content in the analysed products is presented in Table 2, taking into account values in 'ready-to-eat' conditions. The values were captured from literature (Hsu et al., 2004; Nestle, 2018; Regulation, 2018a,b; Sununtnasuk, 2013).

\section{Concentration of deoxynivalenol and zearalenone}

A bibliographic search was carried out to obtain preliminary estimates of the average concentration of DON and ZEA in wheat in Serbia, Croatia and Greece. Figures of DON and ZEA in these three countries that were published in this decade were used to calculate values and ranges (Table 3). Values above limit of detection (LOD) were amended using correction factors in order to take into account effect of cleaning, sorting, milling (correction factors taken from the literature; see results section) and baking (correction factors determined experimentally in

Table 2. Content of wheat in wheat-based products included in this study.

$\begin{array}{lll}\text { Food item } & \text { Portion [g] } & \begin{array}{l}\text { Content of wheat } \\ \text { in final product [\%] }\end{array} \\ \text { White bread } & 40 & 74 \\ \text { Brown bread } & 40 & 59 \\ \text { Wholegrain bread } & 40 & 59 \\ \text { Fine bakery products } & 35 & 55 \\ \text { Bakery products } & 35 & 55 \\ \text { Pastas } & 250 & 45 \\ \text { Crepes } & 25 & 40 \\ \text { Breakfast cereals } & 30 & 40 \\ \text { Cooked wheat } & 30 & 40 \\ \text { Pizza } & 90 & 35 \\ \text { Bars } & 25 & 30\end{array}$


Table 3. Deoxynivalenol (DON) and zearalenone (ZEA) concentration $(\mu \mathrm{g} / \mathrm{kg})$ in wheat in Serbia, Croatia and Greece provided in literature in the last decade.

\begin{tabular}{|c|c|c|c|}
\hline & Serbia & Croatia & Greece \\
\hline \multicolumn{4}{|l|}{ Concentration of DON } \\
\hline Number of samples (positive samples) & $243(189)$ & $147(90)$ & $67(45)$ \\
\hline Mean & $709 \mu \mathrm{g} / \mathrm{kg}$ & $376 \mu \mathrm{g} / \mathrm{kg}$ & $495 \mu \mathrm{g} / \mathrm{kg}$ \\
\hline Range & $10-4,800 \mu \mathrm{g} / \mathrm{kg}$ & $10-3,880 \mu \mathrm{g} / \mathrm{kg}$ & $10-2,446 \mu \mathrm{g} / \mathrm{kg}$ \\
\hline \multicolumn{4}{|l|}{ Concentration of ZEA } \\
\hline Number of samples (positive samples) & $131(78)$ & $156(88)$ & $151(91)$ \\
\hline Mean & $176 \mu \mathrm{g} / \mathrm{kg}$ & $98 \mu \mathrm{g} / \mathrm{kg}$ & $34 \mu \mathrm{g} / \mathrm{kg}$ \\
\hline Range & $5-1,079 \mu \mathrm{g} / \mathrm{kg}$ & $5-982 \mu \mathrm{g} / \mathrm{kg}$ & $5-921 \mu \mathrm{g} / \mathrm{kg}$ \\
\hline References & $\begin{array}{l}\text { (Jajić et al., 2013, 2014; Jakšić } \\
\text { et al., 2012; Krnjaja et al., 2011, } \\
\text { 2015) }\end{array}$ & (Pleadin et al., 2013, 2017a,b) & $\begin{array}{l}\text { (Binder et al., 2007; Griessler } \\
\text { et al., 2010; Irakli et al., 2017; } \\
\text { Skendi et al., 2016) }\end{array}$ \\
\hline
\end{tabular}

this study and provided in the next section). Fixed mean values as provided in the publications were used in further simulations for performing dietary exposure assessment.

\section{Effect of baking on mycotoxins content}

In order to analyse the effects of baking, naturally contaminated flour was used to prepare sample breads were prepared following the recipe: $370 \mathrm{~g}$ of naturally contaminated flour, $7.4 \mathrm{~g}$ salt and $9.25 \mathrm{~g}$ bakers yeast mixed with approximately $200 \mathrm{ml}$ water in order to obtain a $500 \mathrm{~g}$ loaf after baking (Ordinance, 2017). Temperature of baking was $200{ }^{\circ} \mathrm{C}$ for $20 \mathrm{~min}$. Dough and bread samples were oven dried for $24 \mathrm{~h}$ at $48^{\circ} \mathrm{C}$ to reach constant dry weight. Baking tests, for both DON and ZEA, were performed in triplicate.

DON and ZEA in dough and bread samples were determined by ELISA method, using Celer ${ }^{\circledR}$ Techna (Tecna S.r.l., Trieste, Italy) test kits with a LOD of 40 and $10 \mu \mathrm{g} /$ $\mathrm{kg}$, respectively. Analyses were performed according to the manufacturer instructions. In particular, $5 \mathrm{~g}$ of dried dough/bread were mixed with $1 \mathrm{~g}$ of $\mathrm{NaCl}$ and $25 \mathrm{ml}$ of $70 \%$ methanol. After 3 min of shaking, samples were filtered through Whatman 1 filters (Whatman, Maidstone, UK). The filtrate was used in ELISA the assay. ELISA tests were evaluated using a Tecan's Sunrise ${ }^{\text {TM }}$ absorbance micro plate reader (Tecan Trading AG, Männedorf, Switzerland) with an absorbance filter at $450 \mathrm{~nm}$.

\section{Exposure estimation}

The exposure to mycotoxins (DON and ZEA) through product consumption was calculated using data on wheat based products consumption, mycotoxin concentration and body weight, as follows (Pacin et al., 2011):
$\mathrm{EDI}=\frac{\sum_{\mathrm{i}=1}^{\mathrm{n}} \mathrm{P}_{\mathrm{i}} \mathrm{W}_{\mathrm{i}}}{7} * \frac{1}{\mathrm{bw}} * \mathrm{C}_{\mathrm{t}}$

EDI is the estimated daily intake of a certain mycotoxin $\left[\mu \mathrm{g} / \mathrm{kg}\right.$ bw/day]. $\mathrm{P}_{\mathrm{i}}$ is the amount of wheat-based products consumed weekly $[\mathrm{kg}]$. Average daily intake of wheat was calculated when $\mathrm{P}_{\mathrm{i}}$ was divided by seven. $\mathrm{W}_{\mathrm{i}}$ is the content of wheat in the wheat-based product [\%]. Body weight (bw) is expressed in $[\mathrm{kg}] . \mathrm{C}_{\mathrm{t}}$ is the concentration of mycotoxins $[\mu \mathrm{g} / \mathrm{kg}]$.

\section{Statistical analysis}

Chi-Square test for association was used to discover if there are relationships between bread consumption patterns and demographic characteristics of the sample (gender, age and country). The Mann-Whitney $U$ test has been performed to compare the consumption patterns between two groups-categorical variables, such as gender and age. The Kruskal-Wallis $\mathrm{H}$ test has been carried out to compare consumption patterns between more than two groups, such as country. To distinguish statistical differences related to average daily intake, t-test, one-way ANOVA and Tukey's HSD post hoc test were used.

This study used the Monte Carlo analysis of 100,000 simulations - a probabilistic computer simulation method to estimate the intake of DON and ZEA from consumption of wheat-based products. The uncertainty of Monte Carlo variation was assessed in the form of approximate confidence intervals (95\% CIs) of the mean values of exposure to DON and ZEA (Sun and Wu, 2016). Basic descriptive statistical processing was performed using MS Excel (Microsoft, Redmond, WA, USA). Probability distribution fitting for body weight and weekly intake of wheat-based products as well as Monte Carlo simulation was performed using Minitab. 


\section{Results and discussion}

\section{Consumption patterns}

Overall, demographic profile (Table 1) shows that female population slightly prevailed (52.1\%). Distribution of respondents regarding their age showed that half of the sample was considered as younger (below 34 years of age) and a half as older than 35 . Average body weight in the three countries was between 72 and $74 \mathrm{~kg}$. Average daily intake of wheat from wheat-based products taking into account content of wheat provided in Table 2 was statistically different between the three countries $(P<0.05)$ and showed the highest results in Greece $(0.110 \pm 0.064 \mathrm{~kg})$ followed by Serbia $(0.081 \pm 0.056 \mathrm{~kg})$ and Croatia $(0.070 \pm 0.054 \mathrm{~kg})$. Comparing the same genders, average daily intake of wheat from wheat-based products also showed statistically different between the three countries $(P<0.05)$. Also, in Croatia consumption of wheat is statistically different between the genders $(P<0.05)$.

In north European countries, bread appears to be the most consumed wheat based product (Sandvik et al., 2018) and the likely primary source of DON exposure (Pacin et al., 2011). Based on the analysis of the frequency of bread consumption in the three countries, Table 4, it seems that bread is the mostly consumed wheat-based product. Slightly more than half of the respondents confirmed they consume bread more than once a day, whereas twice a day is the most frequent pattern. In addition, this study showed significant association between countries and consumption patterns $(P<0.05)$. Based on the seven days consumption data, quantity of consumed bread compared to other types of wheat-based products was $22.13 \%$ in Greece, $28.98 \%$ in Croatia and 34.34\% in Serbia.

The results also showed that in the three European countries surveyed, $27.8 \%$ of the male population eat bread three times a day or more while only $12.9 \%$ of females eat bread so frequently (Table 4). Chi-Square test for association confirmed slightly different consumption patterns between male and female respondents $(P<0.05)$. Also, statistically significant differences were confirmed in consumption patterns between the younger and older population $(P<0.05)$.

In Serbia and Greece, the majority of the population consumes two slices of bread per meal, while in Croatia it is one slice $(P<0.05$, data not shown). Regarding gender, the majority of females (45.7\%) consume one slice of bread per meal, while $36.6 \%$ of men consume two slices per meal $\left(X^{2}=216.155 ; P<0.05\right.$, data not shown). There was no statistically significant difference between the younger and older population, they all consume a 1-2 slices of bread per meal $(P>0.05)$.

\section{Fate of mycotoxins from wheat to ready to eat form}

In order to obtain exposure assessment to Fusarium mycotoxins, analysis in raw materials must be treated with due care to avoid biased overestimations that do not take impact of milling and processing (EFSA, 2013).

Table 4. Frequency of consumption of bread in Serbia, Croatia and Greece $(n=3,014){ }^{1}$

\begin{tabular}{|c|c|c|c|c|c|c|c|c|}
\hline & $\begin{array}{l}\text { More than } 3 \\
\text { times a day }\end{array}$ & Twice a day & Once a day & $\begin{array}{l}5-6 \text { times a } \\
\text { week }\end{array}$ & $\begin{array}{l}\text { 3-4 times a } \\
\text { week }\end{array}$ & Twice a week & $\begin{array}{l}\text { Once a week } \\
\text { or rare }\end{array}$ & Total \\
\hline \multicolumn{9}{|l|}{ Country ${ }^{2}$} \\
\hline Serbia $^{a}$ & $251(24.8 \%)$ & $358(35.4 \%)$ & $159(15.7 \%)$ & $68(6.7 \%)$ & $82(8.1 \%)$ & $51(5.0 \%)$ & $42(4.2 \%)$ & $1,011(100 \%)$ \\
\hline Croatia $^{b}$ & $222(22.1 \%)$ & $306(30.5 \%)$ & $237(23.6 \%)$ & $56(5.6 \%)$ & $63(6.3 \%)$ & $34(3.4 \%)$ & $85(8.5 \%)$ & $1,003(100 \%)$ \\
\hline Greece $^{c}$ & $130(13.0 \%)$ & $301(30.1 \%)$ & $280(28.0 \%)$ & $62(6.2 \%)$ & $62(6.2 \%)$ & $73(7.3 \%)$ & $92(9.2 \%)$ & $1000(100 \%)$ \\
\hline Overall & $603(20.0 \%)$ & $965(32.0 \%)$ & $676(22.4 \%)$ & $186(6.2 \%)$ & 207 (6.9\%) & $158(5.2 \%)$ & $219(7.3 \%)$ & $3,014(100 \%)$ \\
\hline \multicolumn{9}{|c|}{$X^{2}=118.622 ; P<0.05$} \\
\hline \multicolumn{9}{|l|}{ Gender } \\
\hline Male $^{a}$ & $401(27.8 \%)$ & $421(29.1 \%)$ & $261(18.1 \%)$ & $82(5.7 \%)$ & $93(6.4 \%)$ & $78(5.4 \%)$ & $109(7.5 \%)$ & $1,445(100 \%)$ \\
\hline Female $^{b}$ & $202(12.9 \%)$ & $544(34.7 \%)$ & $415(26.4 \%)$ & $104(6.6 \%)$ & $114(7.3 \%)$ & $80(5.1 \%)$ & $110(7.0 \%)$ & $1,569(100 \%)$ \\
\hline \multicolumn{9}{|c|}{$x^{2}=116.292 ; P<0.05$} \\
\hline \multicolumn{9}{|l|}{ Age } \\
\hline $\begin{array}{l}\text { Young } \\
(<34 y)^{a}\end{array}$ & $260(17.3 \%)$ & $457(30.4 \%)$ & $339(22.6 \%)$ & $116(7.7 \%)$ & $122(8.1 \%)$ & $90(6.0 \%)$ & $118(7.9 \%)$ & $1,502(100 \%)$ \\
\hline $\begin{array}{l}\text { Older }(>34 y)^{b} \\
x^{2}=36.317 ; P\end{array}$ & $\begin{array}{l}343(22.7 \%) \\
<0.05\end{array}$ & $508(33.6 \%)$ & $336(22.2 \%)$ & $70(4.6 \%)$ & $85(5.6 \%)$ & $68(4.5 \%)$ & $102(6.7 \%)$ & $1,512(100 \%)$ \\
\hline
\end{tabular}

${ }^{1}(\mathrm{n})$ represents the frequency of consumption of bread during the observed period; (\%) represents their share in the sample.

2 Items denoted with different superscript letters are significantly different at the level of $5 \%$. 
Sorting and cleaning, a common steps prior to milling, may reduce mycotoxin contamination in wheat, by removing kernels with extensive mould growth, broken kernels, fine materials, and dust (Bullerman and Bianchini, 2007; Kushiro, 2008). This is the material in which most of the toxins accumulate (Pascale et al., 2011; Visconti et $a l ., 2004)$. The concentration of mycotoxins in cleaned wheat, compared to the uncleaned ranges from 7 to $63 \%$ for DON, and from 7 to $40 \%$ for ZEA out of their initial concentrations (Edwards et al., 2011; Lancova et al., 2008; Neuhof et al., 2008).

Milling is the procedure by which whole wheat grains are grounded. During milling mycotoxins may be redistributed and concentrated in certain milling fractions. Most of the studies on milling distribution of mycotoxins in wheat were carried out on DON. Depending on method employed the concentration of DON in white flour or semolina, compared to that in the wheat grain, has ranged from 11 to $89 \%$ of the initial concentration (Abbas et al., 1985). Edwards et al. (2011) reported milling distribution of ZEA of $44 \%$.
Literature review on thermal processing has shown variable reductions in DON depending on the time and temperatures applied. Decrease of DON concentrations was in range from 19.1 to $69.4 \%$ (Abbas et al., 1985), 6 to 16\% (Dropa et al., 2014), while Valle-Algarra et al. (2009) reported reduction rate of $48.6 \%$. ZEA is relatively heat stable and given the thermal stability of the molecule it often survives the treatment (Maragos, 2010). An early report by Gilbert (1989) indicated that about $60 \%$ of ZEA remained after baking of bread, $40-50 \%$ remained after the noodle manufacturing, and $80 \%$ remained after biscuit manufacturing. Due to relatively low number of studies performed on effect of thermal processing on DON and ZEA and high variability of presented results we performed our own study in order to asses this effect. Our study showed a decrease of approximately 20 and $15 \%$ in concentrations of DON and ZEA after baking, respectively, and this was also used as a correction factor in our study. Initial concentrations of DON and ZEA, in dough prior to baking, were $211.0 \pm 33.7$ and $27.8 \pm 3.4 \mu \mathrm{g} / \mathrm{kg}$, while their concentrations in baked bread were $169.6 \pm 6.8$ and $23.7 \pm 3.2 \mu \mathrm{g} / \mathrm{kg}$, respectively.

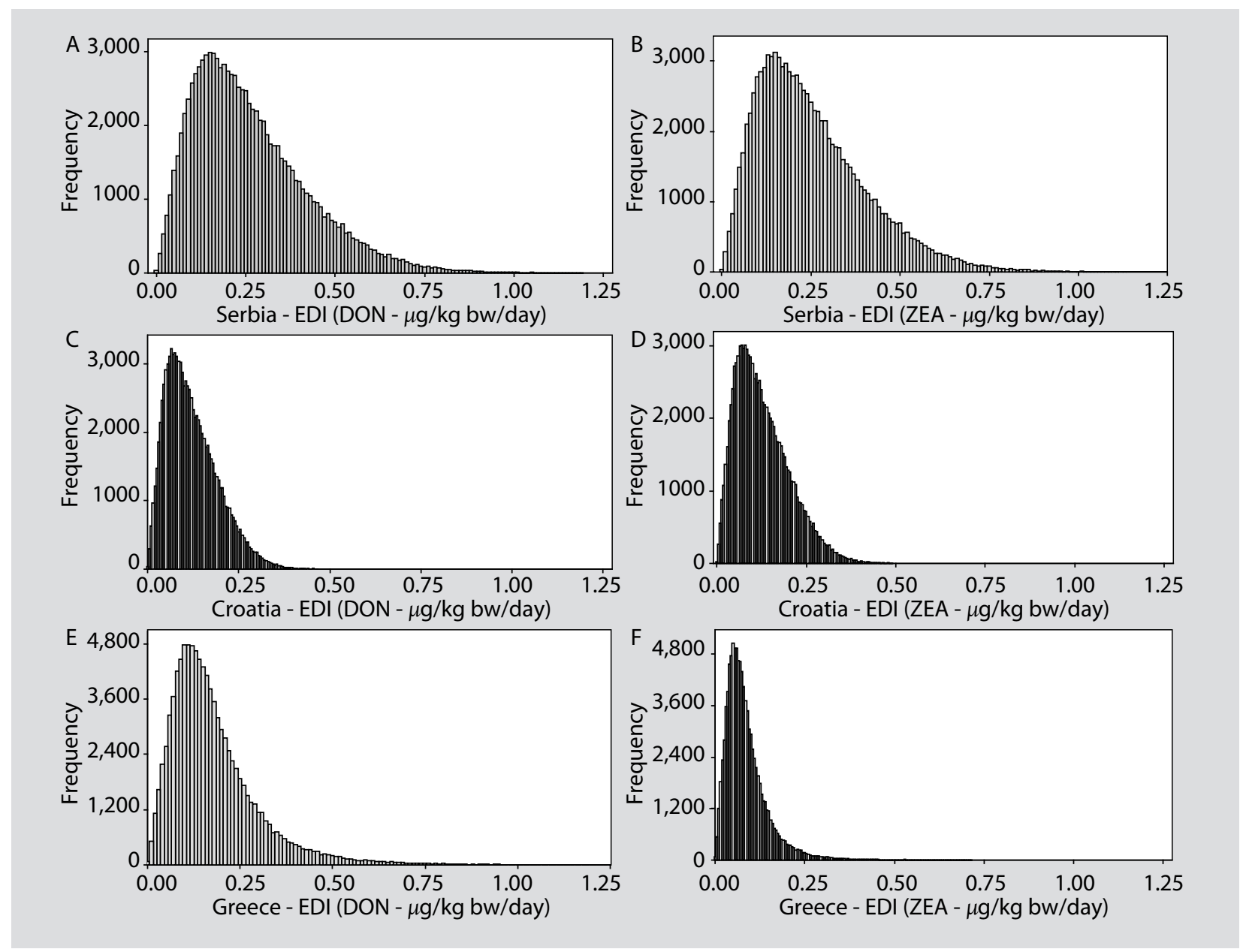

Figure 1. Comparison among estimated total daily intake of mycotoxins after a Monte Carlo analysis of 100,000 simulations. (A) Deoxynivalenol (DON) Serbia; (B) Zearalenone (ZEA) Serbia; (C) DON Croatia; (D) ZEA Croatia; (E) DON Greece; (F) ZEA Greece. 
For this study, following reduction factors along the wheat production chain were taken into the calculation of the concentration of mycotoxins in final, ready to eat products: (a) high correction factor of $60 \%$ regarding DON and $40 \%$ regarding ZEA presence in wheat after cleaning and sorting; (b) medium correction factor regarding to mycotoxins presence in flour milling fraction of $40 \%$, regarding DON, based on the usual methods of milling, and $44 \%$ regarding ZEA; (c) reduction factor of 20 and 15\% for DON and ZEA, respectively, based on baking test. As most products used in this study goes through heat treatment similar to baking, and since bread is the most consumed product, reduction factors obtained via baking tests were used for all products. Concerning products with different production patterns, such as pasta, Visconti et al. (2004) concluded that the retention level of DON from grains on the market to cooked pasta in the plate can be conservatively assessed at $25 \%$ or less. This is in line with final reduction for DON used in this study.

\section{Exposure assessment}

The FAO/WHO (1995) defines exposure assessment as a 'qualitative and/or quantitative evaluation of the likely intake of a chemical agent via food, as well as exposure from other sources if relevant.' To perform such an analysis in this study, contamination and food consumption data were combined to obtain an estimation of the exposure level to DON and ZEA. Consumption data were mathematically treated to represent the average amount $(\mathrm{kg})$ of wheat-based products consumed per day based on weekly consumption reported during field research. This was performed to determine possible risks associated with this type of food since 'risk is a function of the probability of an adverse health effect and the severity of that effect, consequential to a hazard(s) in food' (FAO/WHO, 1995).
Monte Carlo simulation is a method widely used in risk assessment to account for the variability of biological systems (Lindboe et al., 2012). This probabilistic model can quantify which percentage of the population are exposed to risk levels above the TDI/PMTDI (Morales et al., 2011). Our Monte Carlo simulation (Figure 1, Table 5) showed that average exposure of general adult population to DON in Croatia was $0.121 \mu \mathrm{g} / \mathrm{kg}$ bw/day followed by Greece with $0.181 \mu \mathrm{g} / \mathrm{kg}$ bw/day and Serbia with $0.262 \mu \mathrm{g} / \mathrm{kg}$ bw/day. This is below the estimation of FAO/WHO assuming that the total intake of $\mathrm{DON}$ is $1.4 \mu \mathrm{g} / \mathrm{kg}$ bw/day considering European diet (FAO/WHO, 2001). Also, this value is below the TDI/PMTDI values of $1 \mu \mathrm{g} / \mathrm{kg}$ bw/day for DON.

Results obtained in this study were in the range of data obtained by EFSA exposure assessment carried out in 2013 for 21 Member States and Norway (EFSA, 2013). The mean exposure levels for adults, depending on the country, were between 0.17 and $0.32 \mu \mathrm{g} / \mathrm{kg}$ bw/day at the lower bound and 0.25 and $0.46 \mu \mathrm{g} / \mathrm{kg}$ bw/day at the upper bound. The $95^{\text {th }}$ percentile of exposure was between 0.31 and $0.61 \mu \mathrm{g} / \mathrm{kg}$ bw/day at the lower bound and 0.49 and $1.02 \mu \mathrm{g} / \mathrm{kg}$ bw/day at the upper bound. The percentage of adults exposed to DON above $1 \mu \mathrm{g} / \mathrm{kg}$ bw/day was estimated between 0.3 and $5.5 \%$ at the upper bound. Deployed by food groups, the main contributor to mean lower bound DON exposure were 'bread and rolls' representing between 32.1 and $72.3 \%$ of the total exposure. This was followed by 'fine bakery wares' (15.7-34.0\%) in all countries, except in Italy, where 'pasta, raw' was the main contributor (23.9-27.6\%), and Denmark and Hungary, where the food group 'grain milling products' was the main contributor (13.9-23.2\%). In general, with an exception of oat flour, other food groups did not contribute more than $10 \%$ of the total exposure. When considering the upper bound estimates, beer and beer-like beverages were found to contribute to more than $10 \%$ of above $1 \mu \mathrm{g} / \mathrm{kg}$ bw/day per day exposure.

Table 5. Estimated daily wheat-borne intake of deoxynivalenol (DON) and zearalenone (ZEA) for the three countries. ${ }^{1}$

\begin{tabular}{|c|c|c|c|c|c|c|}
\hline & \multicolumn{3}{|c|}{$\mathrm{DON} \mu \mathrm{g} / \mathrm{kg}$ bw/day } & \multicolumn{3}{|c|}{ ZEA $\mu g / k g$ bw/day } \\
\hline & Serbia & Croatia & Greece & Serbia & Croatia & Greece \\
\hline Mean & 0.262 & 0.121 & 0.181 & 0.050 & 0.026 & 0.017 \\
\hline $5^{\text {th }}$ percentile & 0.065 & 0.032 & 0.046 & 0.013 & 0.007 & 0.004 \\
\hline $1^{\text {st }}$ quartile & 0.141 & 0.066 & 0.098 & 0.027 & 0.014 & 0.009 \\
\hline $3^{\text {rd }}$ quartile & 0.351 & 0.164 & 0.229 & 0.068 & 0.035 & 0.022 \\
\hline $95^{\text {th }}$ percentile & 0.570 & 0.259 & 0.415 & 0.109 & 0.055 & 0.041 \\
\hline Population exposed $\geq 1 \mu \mathrm{g} / \mathrm{kg}$ bw DON & $3.96 \%$ & $0.25 \%$ & $1.19 \%$ & & & \\
\hline Population exposed $\geq 0.25 \mu \mathrm{g} / \mathrm{kg}$ bw ZEA & & & & $2.25 \%$ & $0.95 \%$ & $0.62 \%$ \\
\hline
\end{tabular}


Our results showed that $0.25 \%$ of Croatian, $1.19 \%$ of Greek and 3.96\% of Serbian populations are exposed to higher daily dietary intakes as recommended by WHO and FAO. This is below the results revealed in the research in Argentina where $13.5 \%$ of the population would reach the suggested daily dietary intakes for DON (Pacin et al., 2011). The estimated exposure of the adults in Norway to DON from cereal-based food was in the range of 0.27 $0.45 \mu \mathrm{g} / \mathrm{kg}$ bw/day for mean exposure and in the range of $0.55-0.93 \mu \mathrm{g} / \mathrm{kg}$ bw/day for high $\left(95^{\text {th }}\right.$ percentile) exposure in years with low and high DON contamination, respectively (Sundheim et al., 2017). Wheat flour was the main contributor to overall exposure with intake in the range of 141-325 g/day for mean and $95^{\text {th }}$ percentile. Similar results were obtained by Leblanc et al. (2005) as they estimated DON daily intakes by French adult population in the range of 0.28 and $0.57 \mu \mathrm{g} / \mathrm{kg}$ bw, for the mean and $95^{\text {th }}$ percentile exposure, respectively. However, those estimations were a part of Total Diet Study so other types of food were included in calculating estimated exposure to DON. Cereal-derived products contributed over $90 \%$ to this exposure, and particularly the bread/rusk group (between 45 and 70\%) while other non-cereal food groups contributed less than $2 \%$ to the total exposure.

Monte Carlo simulation (Figure 1, Table 5) showed that average exposure of general adult population to ZEA in the three countries was $0.017 \mu \mathrm{g} / \mathrm{kg}$ bw/day in Greece, $0.026 \mu \mathrm{g} / \mathrm{kg}$ bw/day in Croatia and $0.050 \mu \mathrm{g} / \mathrm{kg}$ bw/day in Serbia. These values are below the TDI/PMTDI value of $0.25 \mu \mathrm{g} / \mathrm{kg}$ bw/day for ZEA as recommended by EFSA. Further analysis showed that below one third of the population in these three countries $(0.62 \%$ in Greece, $0.95 \%$ in Croatia and $2.25 \%$ in Serbia) is exposed to this toxin above tolerable daily intakes.

EFSA exposure assessment from 2001 showed that mean dietary exposure to ZEA of the adult population ranged between 0.0024 and $0.029 \mu \mathrm{g} / \mathrm{kg}$ bw/day (minimum lower to maximum upper bound). The $95^{\text {th }}$ percentile exposure ranged from 0.0047 to $0.054 \mu \mathrm{g} / \mathrm{kg}$ bw/day. Grains and grain milling products, bread and fine bakery wares made the largest contribution to the ZEA exposure in all age classes. Although the ZEA concentration in bread was very low, the relatively high contribution to exposure is due to the high consumption. The important contribution of fine bakery wares was explained by the higher concentration of ZEA in this food group due to the high ZEA concentrations found in vegetable oils, especially in corn germ oil and wheat germ oil. Beer and snacks made only a minor contribution to ZEA exposure (EFSA, 2011b).

Another study also identified bread and bread products as major contributors to the exposure to ZEA in adults and children (41\% and 20\%, respectively) (Sirot et al., 2013). Survey conducted in the community of Valencia (Spain) indicated that ZEA was detected in $65 \%$ analysed bread samples, where concentration ranged from 27 to $905 \mu \mathrm{g} /$ $\mathrm{kg}$. Also, results from the same study showed that $30 \%$ of total analysed bread samples exceeded the maximum concentration according to EU legislation (Saladino et al. , 2017). The EDIs calculated for ZEA were 0.0024 and $0.0029 \mu \mathrm{g} / \mathrm{kg}$ bw/day considering the lower and upper bound scenarios, respectively. The \%TDI was $0.95 \%$ for lower upper and $1.17 \%$ for upper bound. Consumption of bread loaves was $0.12,0.03,0.07$ and $0.03 \mathrm{~g} / \mathrm{kg}$ bw/day respectively for white, whole wheat, special and crust less breads loaves with assumed $70 \mathrm{~kg}$ of average bw (Saladino et al., 2017). Aldana et al. (2014) reported that $31.6 \%$ of wheat flour samples obtained from Portugal and Dutch market were contaminated with ZEA. They also estimated that ZEA daily intake from wheat flour consumption for male and female Dutch populations and whole Portuguese adult population, represent $34.8,38.8$ and $19.6 \%$, respectively, of the value proposed by EFSA. These estimations were made based on wheat consumption of $317.3 \mathrm{~g} /$ day for Portuguese population and total cereals consumption of 625.5 and $470.6 \mathrm{~g} /$ day for male and female Dutch population, respectively. Cano-Sancho et al. (2012) estimated ZEA daily intakes by the adults in Catalonia considerably lower than the TDI/PMTDI value. Values were in the range of 0.0009-0.0015 and 0.0025-0.0042 $\mu \mathrm{g} / \mathrm{kg}$ bw/day, for the mean and $95^{\text {th }}$ percentile exposure, respectively. Estimates of ZEA intake by the French adult population of $0.033 \mu \mathrm{g} / \mathrm{kg}$ bw/day were also significantly lower than our estimates (Leblanc et al., 2005). Both of the two latter studies have taken into account several different food types as a source of the ZEA exposure. In Catalonian study next to the pasta and bread, which contributed to the total intake of ZEA with 24.0 and $16.3 \%$, respectively, major contributors were bear and sweet corn with 29.7 and $14.9 \%$ of total ZEA intake, respectively. In France, the food groups contributing with more than $60 \%$ to this exposure in both population groups were cereal-derived products, and particularly the breakfast cereals group.

Fusarium species have optimal temperature and moisture conditions for infection of the cereals, defining their spread and occurrence over regions and years, and subsequent mycotoxin production (Magan et al., 2011). Depending on the climate conditions, the contamination levels of mycotoxins differ worldwide, and therefore maximum admissible levels of mycotoxins in food vary from one country to another (Liu et al., 2015). Good agricultural practices are needed to limit the presence of fungi and mycotoxins in cereal grains during cultivation, followed by good manufacturing/storage practices, further within the cereal production chain (Van der Fels-Klerx et al., 2012).

Our results indicate moderate risks in consuming wheatbased products in these three countries. Prevention of the formation of DON and ZEA should be considered as 
the most effective measure to reduce the levels of these mycotoxins in foodstuffs (Gonzalez-Osnaya and Farres, 2011).

A certain limitation of this study is the complex and dynamic system involved in dietary intake of mycotoxins from the diet, taking into account food processing/cooking steps, mixing with other food matrices and transformation into conjugated mycotoxins, known as the 'masked mycotoxins' (Cano-Sancho et al., 2013). Besides this, food processing plays a role in the chemical transformation of Fusarium toxins, and their potential impact on human health (Berthiller et al., 2013).

This study has a moderate level of uncertainty as a consequence of the considered assumptions such as sample size/country, type of wheat-based products analysed, wheat content in products, correction factors related to food processing steps, derivates of mycotoxins in focus, data used from manuscripts published in the last decade and specification that values below LOD are counted as LOD/2 and certain underestimations for the mycotoxins. The result of uncertainty analysis of Monte Carlo variation shows that for DON, $95 \%$ CI of the mean values for Serbia is $0.2608-0.2628$, for Croatia is $0.1204-0.1213$, for Greece 0.1797-0.1812. For ZEA, 95\% CI of mean values for Serbia is 0.0502-0.0506, for Croatia is 0.0254-0.0257, for Greece is $0.0172-0.0173$. These results have little effect on the upper percentile exposures.

\section{Conclusions}

High variability between reported data on prevalence and concentrations of mycotoxins in wheat, as well as a need on more accurate determination of distribution factors in final products require statistically and bio-technologically relevant sampling plans. Well-designed sampling plans and accurate computation/determination of dilution (or concentration) factors should take into account preharvest and postharvest variabilities, including spatial and temporal agro-climatic impacts. Moreover, it is necessary to recognise contamination of other products with DON / $\mathrm{ZEA}$, and correlate this with respective consumption data to obtain estimates of the overall quantity of mycotoxin to which different segments of Serbian, Croatian, and Greek consumers are exposed to.

Knowing that mycotoxin contamination varies between harvests and based on the literature on DON and ZEA contamination of wheat in East Europe, the authors believe that further research should be focused on monitoring these toxins to re-assess the risks to the population. It is more than necessary to ensure control of wheat-based food by identifying and monitoring the contaminant mycobiota and assessing the levels of these mycotoxins.
This type of research is helpful to assess accurately the risk by DON/ZEA intake associated with the consumption of wheat-based products by consumers in these three countries providing a more adequate quantitative measure of risk. Results may be used by various risk managers/policy makers when making decisions on recommendations and when risk mitigation strategies have to be implemented.

\section{Acknowledgements}

The research leading to these results has received funding from the European Community's Horizon 2020, Call H2020SFS-2015-2 - Integrated and innovative key actions for mycotoxin management in the food and feed chain MYCOKEY.

\section{References}

Abbas, H., Mirocha, C., Pawlosky, R. and Pusch, D., 1985. Effect of cleaning, milling, and baking on deoxynivalenol in wheat. Applied and Environmental Microbiology 50: 482-486.

Aldana, J.R., Silva, L.J., Pena, A., Mañes, J. and Lino, C.M., 2014. Occurrence and risk assessment of zearalenone in flours from Portuguese and Dutch markets. Food Control 45: 51-55.

Berthiller, F., Crews, C., Dall'Asta, C., Saeger, S.D., Haesaert, G., Karlovsky, P., Oswald, I.P., Seefelder, W., Speijers, G. and Stroka, J., 2013. Masked mycotoxins: a review. Molecular Nutrition and Food Research 57: 165-186.

Binder, E., Tan, L., Chin, L., Handl, J. and Richard, J., 2007. Worldwide occurrence of mycotoxins in commodities, feeds and feed ingredients. Animal Feed Science and Technology 137: 265-282.

Bottalico, A. and Perrone, G., 2002. Toxigenic Fusarium species and mycotoxins associated with head blight in small-grain cereals in Europe. European Journal of Plant Pathology 108: 611-624.

Bullerman, L.B. and Bianchini, A., 2007. Stability of mycotoxins during food processing. International Journal of Food Microbiology 119: 140-146.

Calori-Domingues, M.A., Bernardi, C.M.G., Nardin, M.S., De Souza, G.V., Dos Santos, F.G.R., De Abreu Stein, M., Da Gloria, E.M., Dos Santos Dias, C.T. and De Camargo, A.C., 2016. Co-occurrence and distribution of deoxynivalenol, nivalenol and zearalenone in wheat from Brazil. Food Additives and Contaminants Part B 9: 142-151. https://doi.org/10.1080/19393210.2016.1152598

Cano-Sancho, G., Marin, S., Ramos, A. and Sanchis, V., 2012. Occurrence of zearalenone, an oestrogenic mycotoxin, in Catalonia (Spain) and exposure assessment. Food and Chemical Toxicology 50: 835-839.

Cano-Sancho, G., Sanchis, V., Ramos, A. and Marín, S., 2013. Effect of food processing on exposure assessment studies with mycotoxins. Food Additives and Contaminants Part A 30: 867-875. https://doi. org/10.1080/19440049.2013.793824

Denardi de Souza, T., Caldas, S.S., Primel, E.G. and Furlong, E.B., 2015. Exposure to deoxynivalenol, HT-2 and T-2 toxins by consumption of wheat-based product in southern Brazil. Food Control 50: 789793. https://doi.org/10.1016/j.foodcont.2014.10.015 
Dropa, T., Hajslova, J., Lancona, K. and Bureskova, I., 2014. The effect of bread-making process on contents of key trichothecene mycotoxins: deoxynivalenol, T-2, and HT-2 toxins. Czech Journal of Food Science 32: 570-577.

Edwards, S.G., Dickin, E., MacDonald, S., Buttler, D., Hazel, C., Patel, S. and Scudamore, K., 2011. Distribution of Fusarium mycotoxins in UK wheat mill fractions. Food Additives and Contaminants Part A 28: 1694-1704.

European Food Safety Authority (EFSA), 2009. General principles for the collection of national food consumption data in the view of a pan-European dietary survey. EFSA Journal 7: 1435. https://doi. org/10.2903/j.efsa.2009.1435

European Food Safety Authority (EFSA), 2011a. Overview of the procedures currently used at EFSA for the assessment of dietary exposure to different chemical substances. EFSA Journal 9: 2490. https://doi.org/10.2903/j.efsa.2011.2490

European Food Safety Authority (EFSA), 2011b. Scientific Opinion on the risks for public health related to the presence of zearalenone in food. EFSA Journal 9: 2197.

European Food Safety Authority (EFSA), 2013. Deoxynivalenol in food and feed: occurrence and exposure. EFSA Journal 11: 3379. https://doi.org/10.2903/j.efsa.2013.3379

European Food Safety Authority (EFSA), 2016. Appropriateness to set a group health-based guidance value for zearalenone and its modified forms. EFSA Journal 14: e04425.

European Food Safety Authority (EFSA), 2017. Risks for animal health related to the presence of zearalenone and its modified forms in feed. EFSA Journal 15: e04851.

European Union (EU), 2017. EU cereals balance sheets 2016/2017 and 2017/2018. Available at: https://tinyurl.com/y2rvp2ao

Food and Agriculture Organisation (FAO), 2018. Cereal supply and demand brief. Available at: http://www.fao.org/worldfoodsituation/ csdb/en/

Food and Agriculture Organisation/World Health Organisation (FAO/ WHO), 1995. Application of risk analysis to food standards issues. Report of the Joint FAO/WHO Expert Consultation. FAO/WHO, Geneva, Switzerland.

Food and Agriculture Organisation/World Health Organisation (FAO/ WHO), 2001. Safety evaluation of certain mycotoxins in food. FAO, Rome, Italy.

Food and Agriculture Organisation/World Health Organisation (FAO/ WHO), 2010. Joint FAO/WHO expert Committee on food additives. Summary and conclusions. FAO, Rome, Italy.

Gilbert, J., 1989. Current views on the occurrence and significance of Fusarium toxins. Journal of Applied Microbiology 67: 89s-98s.

Gonzalez-Osnaya, L. and Farres, A., 2011. Deoxynivalenol and zearalenone in Fusarium-contaminated wheat in Mexico City. Food Additives and Contaminants Part B 4: 71-78. https://doi.org /10.1080/19393210.2011.551944

Griessler, K., Rodrigues, I., Handl, J. and Hofstetter, U., 2010. Occurrence of mycotoxins in Southern Europe. World Mycotoxin Journal 3: 301-309.

He, J., Zhou, T., Young, J.C., Boland, G.J. and Scott, P.M., 2010. Chemical and biological transformations for detoxification of trichothecene mycotoxins in human and animal food chains: a review. Trends in Food Science and Technology 21: 67-76.
Hsu, C.L., Hurang, S.L., Chen, W., Weng, Y.M. and Tseng, C.Y., 2004. Qualities and antioxidant properties of bread as affected by the incorporation of yam flour in the formulation. International Journal of Food Science and Technology 39: 231-238.

Irakli, M.N., Skendi, A. and Papageorgiou, M.D., 2017. HPLC-DADFLD method for simultaneous determination of mycotoxins in wheat bran. Journal of Chromatographic Science 55: 690-696.

Jajić, I., Krstović, S., Kos, J. and Abramović, B., 2014. Incidence of deoxynivalenol in Serbian wheat and barley. Journal of Food Protection 77: 853-858.

Jajić, I.M., Krstović, S.Z., Perišić, B.Č., Jakšić, S.M., Bursić, V.P., Jevtić, R.M. and Abramović, B.F., 2013. Presence of zearalenone in the most commonly grown wheat cultivars in Serbia. Zbornik Matice srpske za prirodne nauke: 124: 101-109.

Jakšić, S., Abramović, B., Jajić, I., Baloš, M.Ž., Mihaljev, Ž., Despotović, V. and Šojić, D., 2012. Co-occurrence of fumonisins and deoxynivalenol in wheat and maize harvested in Serbia. Bulletin of Environmental Contamination and Toxicology 89: 615-619.

Khaneghah, A.M., Martins, L.M., Von Hertwig, A.M., Bertoldo, R. and Sant'Ana, A.S., 2018. Deoxynivalenol and its masked forms: characteristics, incidence, control and fate during wheat and wheatbased products processing - a review. Trends in Food Science and Technology 71: 13-24. https://doi.org/10.1016/j.tifs.2017.10.012

Kimura, M., Tokai, T., Takahashi-Ando, N., Ohsato, S. and Fujimura, M., 2007. Molecular and genetic studies of Fusarium trichothecene biosynthesis: pathways, genes, and evolution. Bioscience, Biotechnology, and Biochemistry 71: 2105-2123.

Knutsen, H.K., Alexander, J., Barregård, L., Bignami, M., Brüschweiler, B., Ceccatelli, S., Cottrill, B., Dinovi, M., Grasl-Kraupp, B. and Hogstrand, C., 2017. Risks to human and animal health related to the presence of deoxynivalenol and its acetylated and modified forms in food and feed. EFSA Journal 15: 4718.

Krnjaja, V., Tomić, Z., Stanković, S., Petrović, T., Bijelić, Z., Mandić, V. and Obradović, A., 2015. Fusarium infection and deoxynivalenol contamination in winter wheat. Biotechnology in Animal Husbandry 31: 123-131.

Krnjaja, V.S., Lević, J.T., Stanković, S.Ž. and Stepanić, A.M., 2011. Fusarium species and their mycotoxins in wheat grain. Zbornik Matice srpske za prirodne nauke 120: 41-48.

Kushiro, M., 2008. Effects of milling and cooking processes on the deoxynivalenol content in wheat. International Journal of Molecular Sciences 9: 2127-2145.

Lancova, K., Hajslova, J., Kostelanska, M., Kohoutkova, J., Nedelnik, J., Moravcova, H. and Vanova, M., 2008. Fate of trichothecene mycotoxins during the processing: milling and baking. Food Additives and Contaminants 25: 650-659.

Leblanc, J.-C., Tard, A., Volatier, J.-L. and Verger, P., 2005. Estimated dietary exposure to principal food mycotoxins from the first French Total Diet Study. Food Additives and Contaminants 22: 652-672.

Li, F., Jiang, D., Zhou, J., Chen, J., Li, W. and Zheng, F., 2016. Mycotoxins in wheat flour and intake assessment in Shandong province of China. Food Additives and Contaminants Part B 9: 170-175. https://doi. org/10.1080/19393210.2016.1154109 
Lindboe, M., Henrichsen, E., Høgåsen, H. and Bernhoft, A., 2012. Lead concentration in meat from lead-killed moose and predicted human exposure using Monte Carlo simulation. Food Additives and Contaminants Part A 29: 1052-1057.

Liu, Y., Lu, Y., Wang, L., Chang, F. and Yang, L., 2015. Survey of 11 mycotoxins in wheat flour in Hebei province, China. Food Additives and Contaminants Part B 8: 250-254. https://doi.org/10.1080/193 93210.2015.1074291

Magan, N., Medina, A. and Aldred, D., 2011. Possible climatechange effects on mycotoxin contamination of food crops pre-and postharvest. Plant Pathology 60: 150-163.

Manova, R. and Mladenova, R., 2009. Incidence of zearalenone and fumonisins in Bulgarian cereal production. Food Control 20: 362-365.

Maragos, C., 2010. Zearalenone occurrence and human exposure. World Mycotoxin Journal 3: 369-383.

Morales, J.S.S., Rojas, R.M., Pérez-Rodríguez, F., Casas, A.A. and López, M.A.A., 2011. Risk assessment of the lead intake by consumption of red deer and wild boar meat in Southern Spain. Food Additives and Contaminants Part A 28: 1021-1033. https://doi.org/10.1080 /19440049.2011.583282

Nestle, 2018. Wheat, corn and their products in food. Available at: https://www.nestle-cereals.com.

Neuhof, T., Koch, M., Rasenko, T. and Nehls, I., 2008. Occurrence of zearalenone in wheat kernels infected with Fusarium culmorum. World Mycotoxin Journal 1: 429-435.

Ordinance, 2017. Regulation on production and trade of bread made from flour type ‘T-500' In: O.G.o.t.R.o. Serbia (ed.) Government of the Republic of Serbia, Belgrade, Serbia.

Pacin, A.M., Resnik, S.L. and Martinez, E.J., 2011. Concentrations and exposure estimates of deoxynivalenol in wheat products from Argentina. Food Additives and Contaminants Part B 4: 125-131. https://doi.org/10.1080/19393210.2011.564401

Pascale, M., Haidukowski, M., Lattanzio, V.M.T., Silvestri, M., Ranieri, R. and Visconti, A., 2011. Distribution of T-2 and HT-2 toxins in milling fractions of durum wheat. Journal of Food Protection 74: 1700-1707.

Pestka, J.J., 2010. Deoxynivalenol: mechanisms of action, human exposure, and toxicological relevance. Archives of Toxicology 84: 663-679. https://doi.org/10.1007/s00204-010-0579-8

Pinton, P., Braicu, C., Nougayrede, J.-P., Laffitte, J., Taranu, I. and Oswald, I.P., 2010. Deoxynivalenol impairs porcine intestinal barrier function and decreases the protein expression of claudin- 4 through a mitogen-activated protein kinase-dependent mechanism. Journal of Nutrition 140: 1956-1962.

Pleadin, J., Frece, J., Lešić, T., Zadravec, M., Vahčić, N., Malenica Staver, M. and Markov, K., 2017a. Deoxynivalenol and zearalenone in unprocessed cereals and soybean from different cultivation regions in Croatia. Food Additives and Contaminants Part B 10: 268-274.

Pleadin, J., Staver, M.M., Markov, K., Frece, J., Zadravec, M., Jaki, V., Krupić, I. and Vahčić, N., 2017b. Mycotoxins in organic and conventional cereals and cereal products grown and marketed in Croatia. Mycotoxin Research 33: 219-227.

Pleadin, J., Vahčić, N., Perši, N., Ševelj, D., Markov, K. and Frece, J., 2013. Fusarium mycotoxins' occurrence in cereals harvested from Croatian fields. Food Control 32: 49-54.
Regulation, 2018a. Regulation on production and trade of breat type T-500 / Uredba o obaveznoj proizvodnji i prometu hleba od brašna „T-500'. In: O.G.o.t.R.o. Serbia (Ed.). Government of the Republic of Serbia, Belgrade, Serbia.

Regulation, 2018b. Regulation on qualiy of wheat, bakery products and pasta / Pravilnik o kvalitetu žita, mlinskih i pekarskih proizvoda i testenina. In: O.G.o.t.R.o. Serbia (Ed.). Government of the Republic of Serbia, Belgrade, Serbia.

Saladino, F., Quiles, J.M., Mañes, J., Fernández-Franzón, M., Luciano, F.B. and Meca, G., 2017. Dietary exposure to mycotoxins through the consumption of commercial bread loaf in Valencia, Spain. LWT - Food Science and Technology 75: 697-701.

Sandvik, P., Nydahl, M., Kihlberg, I. and Marklinder, I., 2018. Consumers' health-related perceptions of bread - implications for labeling and health communication. Appetite 121: 285-293. https://doi.org/10.1016/j.appet.2017.11.092

Savi, G.D., Piacentini, K.C., Tibola, C.S., Santos, K., Sousa Maria, G. and Scussel, V.M., 2016. Deoxynivalenol in the wheat milling process and wheat-based products and daily intake estimates for the Southern Brazilian population. Food Control 62: 231-236. https:// doi.org/10.1016/j.foodcont.2015.10.029

Savi, G.D., Piacentini, K.C., Tibola, C.S. and Scussel, V.M., 2014. Mycoflora and deoxynivalenol in whole wheat grains (Triticum aestivum L.) from Southern Brazil. Food Additives and Contaminants: Part B 7: 232-237. https://doi.org/10.1080/19393 210.2014.898337

Siou, D., Gélisse, S., Laval, V., Suffert, F. and Lannou, C., 2015. Mutual exclusion between fungal species of the Fusarium head blight complex in a wheat spike. Applied and Environmental Microbiology 81: 4682-4689.

Sirot, V., Fremy, J.-M. and Leblanc, J.-C., 2013. Dietary exposure to mycotoxins and health risk assessment in the second French total diet study. Food and Chemical Toxicology 52: 1-11.

Skendi, A., Irakli, M.N. and Papageorgiou, M.D., 2016. Optimized and validated high-performance liquid chromatography method for the determination of deoxynivalenol and aflatoxins in cereals. Journal of Separation Science 39: 1425-1432.

Stanciu, O., Banc, R., Cozma, A., Filip, L., Miere, D., Mañes, J. and Loghin, F., 2015. Occurrence of Fusarium mycotoxins in wheat from Europe - a review. Acta Universitatis Cibiniensis. Series E: Food Technology 19: 35-60.

Sun, J. and Wu, Y., 2016. Evaluation of dietary exposure to deoxynivalenol (DON) and its derivatives from cereals in China. Food Control 69: 90-99.

Sundheim, L., Lillegaard, I.T., Fæste, C.K., Brantsæter, A.-L., Brodal, G. and Eriksen, G.S., 2017. Deoxynivalenol exposure in Norway, risk assessments for different human age groups. Toxins 9: 46.

Sununtnasuk, C., 2013. Calculating wheat flour consumption: sources and methods, smarter futures cost and economic benefit training workshop. International Food Policy Research Institute (PHND), Dar es Salaam, Tanzania.

Valle-Algarra, F.M., Mateo, E.M., Medina, A., Mateo, F., GimenoAdelantado, J.V. and Jiménez, M., 2009. Changes in ochratoxin A and type $B$ trichothecenes contained in wheat flour during dough fermentation and bread-baking. Food Additives and Contaminants Part A 26: 896-906. 
Van der Fels-Klerx, H.J., Klemsdal, S., Hietaniemi, V., Lindblad, M., Ioannou-Kakouri, E. and Van Asselt, E.D., 2012. Mycotoxin contamination of cereal grain commodities in relation to climate in North West Europe. Food Additives and Contaminants Part A 29: 1581-1592. https://doi.org/10.1080/19440049.2012.689996

Vidal, A., Sanchis, V., Ramos, A.J. and Marín, S., 2016. The fate of deoxynivalenol through wheat processing to food products. Current Opinion in Food Science 11: 34-39. https://doi.org/10.1016/j. cofs.2016.09.001
Vilone, G., Comiskey, D., Heraud, F. and O'Mahony, C., 2014. Statistical method to assess usual dietary intakes in the European population. Food Additives and Contaminants Part A 31: 1639-1651. https:// doi.org/10.1080/19440049.2014.955886

Visconti, A., Haidukowski, E.M., Pascale, M. and Silvestri, M., 2004. Reduction of deoxynivalenol during durum wheat processing and spaghetti cooking. Toxicology Letters 153: 181-189. 